EDYTA LOREK-JEZIŃSKA Nicolaus Copernicus University in Toruń*

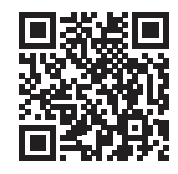

\title{
Feminist Transgressions and Critical Dys-u-topian Drama: Ann Jellicoe, Bryony Lavery and Germaine Greer
}

\begin{abstract}
Referring to the discussion on the critical potential of dystopias in fiction, the article examines twentieth century feminist plays by Ann Jellicoe, Bryony Lavery and Germaine Greer for their presentation and critical deconstruction of gender roles, social structures and power relations. In the plays discussed in the article the critical and transgressive strategies used by the playwrights question the possibility of separating utopias and dystopias, showing how they are linked to and dependent on each other. Refusing to provide neat endings and definitions, the plays open up to contradictory readings by mixing the elements of dystopia and utopia and inviting critical and self-reflexive interpretations directing the critique of the past and the future towards the present.
\end{abstract}


* Department of Anglophone Literary, Cultural and Comparative Studies, Institute of Literary Studies, Nicolaus Copernicus University in Torun

Bojarskiego 1,87-100 Toruń

e-mail: lorek@umk.pl 


\section{Introduction}

The critical power of dystopias, as many researchers would agree, stems not from their visions of the worst possible scenarios but from their close affinity to and entanglement with utopia. As the editors of the volume on Utopia/Dystopia: Conditions of Historical Possibility write, "dystopia is not simply the opposite of utopia [...] rather it is a utopia that has gone wrong, or a utopia that functions only for a particular segment of society" (Gordin, Tilley and Prakash 2010: 1). In the context of feminist texts such a selective functioning of utopia would be often associated with the consequences of the domination of one gender over the other, in a strongly polarized society along binary gender lines. The critique of such a polarization might in fact lead to using the same divisions that seem to lie at the roots of the primary injustice, thus reinforcing the rules that it aimed to question. In her study of "contemporary female dystopias", Dunja M. Mohr (2005) emphasises the significance of transgressions that challenge dichotomic thinking and disturb polar divisions, in this way questioning what at some point Toril Moi described as "death-dealing binary thought" (qtd. after Cixous 1986: 210) or "death-dealing binary oppositions of masculinity and femininity" (Moi 1994: 13). Mohr focuses on what she calls "feminist transgressive utopian dystopias" which she describes as hybrid texts involving a number of transgressions - and whose main features include the presence of the utopian undercurrent in the dystopia as well as the rejection of the traditional binary structure of majority of dystopias (2005: 3). Jane Donawerth sees "the borders between utopia and dystopia" as "permeable" and names dystopia as a genre particularly suitable for "generic blends" (2003: 29). These transgressive qualities of dystopias can be linked with post-apocalyptic culture and its ambivalences of endings and beginnings in the times after the catastrophe as well as its questioning of categories and old truths, often ascribed to millennial crisis and postmodernism. Both aspects are related to what Teresa Heffernan describes as "the abandonment of an ultimate ending, or at least a recognition that the focus on a particular end limits other imagined worlds" that can be seen as "an ethical move that breaks down the binary between the Christ and Antichrist model as it allows for a world that remains open in its direction, available to other headings" (2008: 13). The aspect of open endings is also crucial to the category of the critical dystopia discussed by Raffaella Baccolini and Tom Moylan in their introduction to Dark Horizons: Science Fiction and 
the Dystopian Imagination. The authors define critical dystopias as the ones that "maintain a utopian impulse" and "resist closure", whereby "open[ing] a space for contestation and opposition" (Baccolini and Moylan 2003: 7). In doing so they resist the bleakness, depression and pessimism associated with dystopias and leave space — beyond or outside the text - for hope and negotiation (Baccolini and Moylan 2003: 7).

This aspect of openness characteristic of post-apocalyptic and critical dystopian visions is closely related to and affected by the dystopia's reference to the category of time, and its temporary and spatial displacements. In his book After the End, James Berger comments on the affinity between apocalypse and trauma in that they can be read only through "the portents and symptoms that precede and follow it" and "[force] a retelling and revaluing of all events that lead up to it and all that follow" (Berger 1999: 21). The aspect of dystopia (and utopia) that makes it particularly evocative and relevant is its reference to the present times and contemporary societies: dystopias expose negative and undesirable tendencies in the present time and project them - often in an exaggerated manner - into the future. Both utopias and dystopias are called "histories of the present" by Michael Gordin, Hellen Tilley and Gyan Prakash (2010: 1). Utopias "render present-day problems more clearly" while dystopias "[place] us directly in a dark depressing reality, conjuring up a terrifying future if we do not recognize and treat its symptoms in here and now" (Gordin, Tilley and Prakash 2010: 2). Utopias and dystopias are placed in between the past, the present and the future, with dystopias being mostly influenced by what Gordin, Tilley and Prakash name "lived experience" (2010: 2) closer to the readers' frame of reference.

\section{Critical dys-u-topias: Ann Jellicoe, Bryony Lavery and Germaine Greer}

All the three plays examined in this article, The Rising Generation (1957) by Ann Jellicoe, More Light by Bryony Lavery (1997) and Lysistrata — The Sex Strike (1999) by Germaine Greer and Phil Willmott (after Aristophanes) share a commentary on the power relation between men and women, show violence of one gender against the other and are based on the sex role reversal motif. They realise women's empowerment in extreme and subversive ways, destabilising the patriarchal system but also deconstructing their own ways of gaining power. All of them place the characters in the critical situation of danger or imminent death as a result of: nuclear and environmental self-destruction (The Rising Generation), being buried alive (More Light) or wars fought by men (Lysistrata). But most importantly, all three fuse the elements of dystopia and utopia in ambivalent ways, problematizing the complex nature of social systems and structural solutions. By this they offer a critique not only of patriarchal relations and an imbalance of power, but also the binary ways of reversing the power relations to similarly dystopian ends.

What Jellicoe's, Lavery's and Greer's plays have additionally in common is their postapocalyptic or catastrophic vision either in relation to the past or the future as well as large casts and experimental forms (as the consequence of the social scale of utopias and dystopias). The first two plays were written for young performers and young audiences, with implied educational agendas. Jellicoe's play was originally commissioned by the Girl Guides Association in 1957 and was to engage 800 girls and 100 boys (it was rejected and then performed with a smaller cast) (Keyssar 1993: 44-45). More Light by Bryony Lavery was commissioned for the National Theatre Connections programme offering plays for young 
actors authored by "the UK's most exciting writers" 1 and was performed by Sandbach School, Cheshire in 1997 (Lavery 2007: 287). All three writers are in some ways connected to feminism and their plays largely reflect feminist approaches to gender relations, however, with varying degrees of explicitness and commitment. Ann Jellicoe "precursor" of feminist plays, as Helene Keyssar argues, presents effectively the feminist aesthetics, addresses "contemporary feminist issues" but at the same time are ambiguous and "vulnerable to criticisms of a dangerous sexism” (1993: 50). Bryony Lavery explicitly addresses feminist and lesbian issues in her plays, openly admitting to their both political and feminist content (Lavery 2005a: 40), yet also emphasising that theatre should be addressed to all people no matter what their views and identities (Lavery 2005b: 307). Germaine Greer, an Australian writer and feminist, the author of The Female Eunuch (1969) and one of major albeit controversial representatives of the second wave feminism, wrote in her introduction to a collection of essays: "The question is often asked of me now, 'Are you still a feminist?' as if it were possible for me to be anything else. Everything I learn reinforces my conviction that the only corrective to social inequality, cruelty and callousness, is to be found in values which, if we cannot call them female, can be called sororal. They are the opposite of competitiveness, acquisitiveness and domination, and may be summed by the word 'co-operation"' (Greer 1986: xxvi). Her adaptation/appropriation of Lysistrata, with all its carnivalesque and low comedic appeal, centres upon the questions of solidarity and cooperation between women.

\section{Gender reversals and utopia of equality}

The Rising Generation by Ann Jellicoe can be in general terms classified as the sex role-reversal science fiction play. Role-reversal fiction is defined as a conservative genre, popular between the 1920s and the end of the 1970s, whose ultimate aim is to restore the old unjust yet seemingly "natural" order of things (Donawerth 2003: 30). Such an interpretation seems to loom from the editor's commentary, describing the play's vision of matriarchal society ${ }^{2}$ as resulting "from mass prejudice in an age of inverted standards", where mother nature "is projected ... with nightmarish horror" as "savage and destructive, a perversion of the norm" (Durband 1969: 8). From a certain perspective, Jellicoe's play follows most of the features of this fictional subgenre, as it contains the love plot (albeit on a more symbolic and collective level), the critique of new unjust semi-matriarchal society modelled on the patriarchal system of power, and ultimately "reinforces the heterosexual patriarchy as the status quo" (Donawerth 2003: 30). What makes it possible to read it as an instance of the critical dystopia is its postapocalyptic context that projects the situation depicted in the play into the future but also into the past. Following the action of "analysing and diagnosing the remainder, the ruins of the world that persist after the unspeakable trauma, after its end" (Heffernan 2008: 6), it is possible to trace back but also forward the situation depicted in the play to another prior injustice as the result of which the matriarch and her supporters seized power from men and established their rule. It is by seeing what happens once the matriarchal regime is seemingly justly overthrown that one begins to understand the reasons behind the role reversal scheme - that the degree to which the dystopian matriarchal system is based on

1 https://www.nationaltheatre.org.uk/learning/connections [access: 12.09.2019].

2 I discussed the notion of matriarchy and gender polarity in Jellicoe's play more extensively in "Between the generic he and the generic she: the cultural re-definition of gender polarity in Ann Jellicoe's The Rising Generation". 
hatred, discrimination, ignorant indoctrination and violence only shows - intentionally or not - the degree to which the former social system suppressed and oppressed women. Men's holocaust in the play testifies to the earlier holocaust of women and minorities. The system of women's rule exposes how they were treated before the change of power: their primitive domination is founded on ignorance and appropriation (of men's achievements because they had none) as a result of poor training and restricted education, on prejudice resulting from inexperience, and on violence caused by their fear of men's strength and power. The past injustice becomes particularly visible in the way men's dominance is resumed at the end of the play after humans have to rescue themselves by building a spaceship and fleeing to another planet: power is smoothly regained through seemingly natural leadership and technological expertise, pushing women once again into subordinate and minor positions.

The moment in which the feminist dystopia becomes suspended is the young girls' discovery of the "true" nature of men, and the fascination with their difference, which parallels the motives found in other cases of role reversal science fiction discussed by Donawerth (2003: 30). In a dance scene the girls start to notice the boys and together form pairs, introduce themselves and start dancing, disobeying their teacher. The utopian core of the play is their mutual declaration of the importance of both man and woman and their dependence on each other, accompanied by their newly gained wisdom that "a threat to all is a threat to each/ a threat to each is a threat to all” (Jellicoe 1969: 55). The young generation that manages to flee from the earth in a spaceship constructed by a male expert after the Mother destroys everything with an atomic explosion hopes to establish a just and democratic society, which (just) happens to rely for its new beginning on men's organizational and scientific skills. The play's structural open ending can be seen - at least to some extent - as a hope for the balancing of powers and carefulness in future decisions that the lesson of men's holocaust and nuclear catastrophe has taught young people. The ease with which the patriarchy seems to naturally reinstate itself in this new society might be seen as no more than a hopeful warning.

In her commentary on the plays by Ann Jellicoe, Helene Keyssar emphasises the feminist impulse in her plays, but notices how Jellicoe presents both female and male characters' confusion about the notions of strength, on the one hand, and violence and power, on the other. What is particularly significant according to Keyssar is uncertainty, confusion or lack of clarity in the plays' intent (1993: 45-46), which contribute to the critical potential of her dystopian visions.

\section{Subversive nightmares and ironic futures}

More Light by Bryony Lavery realizes the scenario of sex reversal dystopia in a particularly subversive manner. Similarly to feminist dystopias discussed by Mohr in the field of fiction, Lavery's play is preoccupied with the issues of reproduction, women's bodies, their biological functions and their abuse as well as fascinations with the male absolute power (Mohr 2005: 36). The play pushes the patriarchal power and women's subjugation into the macabre extreme, which is represented by the act of burying wives and concubines of the emperor alive together with his corpse. The story of role reversal is in this case the story of survival, as women have to resort to cannibalism and warfare to find sustenance. The earlier objectification of women and their corporealities ${ }^{3}$ through their sexual and reproductive attributes is

3 For the discussion of corporeality and archaeology in More Light, see Lorek-Jezińska Edyta (2009), "Burial, Excavation and Cannibalism: The Body's Discursivity in Bryony Lavery's Drama". 
reversed in the underground world and transformed into the objectification of men and their bodies as nourishment. The act of objectification is ideologically justified by the Emperor's women through exaggeration of allegedly positive attributes of masculinity. Thus female characters cunningly base their decision to resort to cannibalism on the arguments of care, protection, power and wisdom that they can expect from but also share with the men. They turn to the emperor's body for food, because "he has always fed" and protected them (Lavery 2007: 302); they have to "look to the most special workings of the most special minds in the Empire", also entombed with them in another circle, to solve the problem of food supply as their minds are not used to such effort (Lavery 2007: 313). In a mock ritual the women claim that through cannibalism they have gained the attributes of the men they consumed and now can call themselves: "Emperors of our world. Let us be its mathematicians, astrologers, metalsmiths, artists, inventors, architects. As the Emperor constructed his tomb so let us construct our world!" (Lavery 2007: 327). Like in role reversal science fiction, there is a romance motif, when one of the Emperor's women starts to feel affection for a young man (from the outer circle of the tomb), castrated by the Emperor for theft. She hesitates whether to kill him, yet his attempt to prove his usefulness is based on assumptions of men's physical and intellectual superiority, and finally weighs against him, as More Light, the eponymous character, realizes that the world outside is no different to slow death in the tomb. Thus the romantic element involving - to use Joanna Russ's phrase - "some form of phallic display" (qtd. in Donawerth 2003: 30) and which leads to the return of the older system of men's superiority (Donawerth 2003: 30) is subverted in Lavery's play. The "phallic display", physically incomplete, but emotionally - through pity and compassion - potentially more effective, in its discursive form produces counteraction - based on the realisation of the threat of men's power. More Light's decision to stay in the tomb in the world governed by women and doomed to death is a critical commentary on the status and life available to women in the "normal" surface society.

In literal terms, the world depicted in Lavery's play presents a bleak and macabre vision of women's existence - their live burial and slow death, the more poignant as at some stage it is still preferable to living in a patriarchal society on the surface. However, this dystopian vision is combined with the trace of utopia and the post-apocalyptic narrative, complexifying the final interpretation. While the utopia of women's power and achievement realised in the women's subterranean existence only exposes the horror of the dystopian situation, the final scene and its earlier premonitions open up the play to more complex readings. The last part of the play called "The transfiguration" shows the scene of two archaeologists - a man and a woman - uncovering the tomb and opening it, with the daylight flooding the stage. The light exposes the figures of the Emperor's women - motionless and by that time dead, the bronze army - and "millions and millions" (Lavery 2007: 373) of origami paper birds falling from the ceiling onto the ground. The archaeologists - left almost speechless by what they see - only manage to say a simple phrase "Poor bastards!", which apparently trivialises what happened to the women and men in the tomb. However, such a trivialisation occurs in a future world where perhaps the Emperor's women's story is unimaginable because the frames of reference have changed so radically. And in this sense - although the story is lost and women's art makes but a short (albeit spectacular) appearance - the utopian moment is contained in the casual manner in which Modern Man and Woman together comment on their discovery. The play's temporal structure might in fact support this reading - the 
nightmare of the past dystopia is separated from the future/present utopia by time and space - one belongs to the archaeological past and subterranean level, while the other to the projected present and the surface world.

However, in the text so much driven by irony and subversive strategies there seems to be no space left for either dystopia or utopia proper. The underground horror might be read when seen from a different perspective - as the undercurrent suppressed nightmare haunting the present times through traumatic memories and posing a threat to the new social order. The final transfiguration can be read as an ironic commentary on the miraculous transformation of the absolute patriarchal power and women's cannibalism into the social structure based on the equality of the sexes, or on the rising of the dead women into the air as origami birds, a form of spiritual or artistic compensation for their traumatic experience. Both options - when compared with the horror of what they went through - sound inadequate and naively optimistic. This much too smooth and open ending leaves these subversive realisations of dystopian nightmarish visions unfinished, questioning some of the possible mostly metaphorical - extensions into the contemporary world.

\section{Feminist utopias and the underprivileged}

The last play to be discussed, Lysistrata - the sex strike, is based on the battle of the sexes paradigm and presents the utopian vision of sex role reversal. It is a loose adaptation of the play by Aristophanes and foregrounds the aspects of pacifism and gender struggle. Similarly to the plays by Jellicoe and Lavery, Lysistrata was designed, as stage directions suggest, for a large cast, with groups of people crossing the stage and participating in most of the scenes (Willmott 2000: 8). Often staged in site-specific locations, the set presents the baths destroyed by the war, dilapidated with "a gaping hole in the back wall" (Willmott 2000: 7) - the result of bombing. In the background "occasional loud explosions and bursts of machine-gun fire" (Greer 2000: 9) can be heard. Despite this catastrophic setting and the serious matter it addresses, the play is supposed to be acted in the manner of Carry On films; this suggestion concerns all the characters but the cleaning ladies, who are to be acted more naturally. The main plotline revolves around the character of Lysistrata and her successful plan of forcing the men to end the war and sign a peace treaty by going on the sex strike. In that it seems to largely recreate the original plot, together with its phallic humour and obscenities (Eanowski 1981: L), adding to it the twentieth century context, contemporary music and warfare. In as much as it follows the plot of the ancient comedy, the play presents a utopian idea of the power of women to change the world into a better one - despite its sexist humour which attacks both men and women almost equally.

What makes this adaptation different is another theme that appears in the background the one of class and invisibility. While the plot based on Aristophanes' play is enacted, another one - largely inconspicuous - develops around the characters of the cleaning ladies, who - as the stage directions suggest - are not noticed by other characters. The eponymous Lysistrata, who teaches about women's solidarity, "takes no notice of the cleaning women. It is as though they are invisible. When she removes her cloak she simply holds it out expecting someone to take it from her - and they do" (Greer 2000: 9-10). The cleaning women are also ignored by other female characters and instantly lose their visibility to men, when they reveal who they are. When they are asked to leave the baths as the "Men Only" area, one 
of them replies: "Well, ain't that strange? We've been coming in here every night to scrub the place from top to bottom. If we'd known, we wouldn't have bothered" (Greer 2000: 36).

The most poignant commentary appears at the end of the play, when Aristophanes' plot reaches its end and men and women celebrate the cease-fire and express the hope of the future free from wars and conflicts. The cleaning women are not admitted into the palace and receive a violent welcome from the doorman. The play ends on a dystopian note with a number of questions asked and some left without an answer. The final lines emphasise the difference between fantasy and reality:

Stratyllis: Lysistrata is the heroine of Aristophanes' fantasy. That's how she won the Acropolis and united the women and defied the Probuli. In real life Athens was destroyed by the war. This has all been an old man's wartime fantasy.

Katina: But we're the peasant women of Greece, as real as rocks and stones. Why can't we be in the happy fantasy? (Greer 2000: 96)

The open ending throws a different - more critical - light on the utopian myth and idealized fantasy, asking questions of social visibility and agency. It also emphasizes various positions that women from different social groups occupy in relation to violence and patriarchy. And finally, they expose the lack of solidarity between women - both male and female characters follow the same strategies of ignoring the presence of other classes in their world.

\section{Conclusion}

The critical dystopias contained in the plays by Jellicoe, Lavery and Greer rely for their effect on the conventions of sex reversal narratives, which they use with critical distance, dark humour or parodic twist. They combine and mix the elements of utopian fantasy and dystopian reality or nightmare, showing the extent to which one is implicated in the other or the ease with which one can transform into its opposite. In that respect, they follow the tendency to write or think about dystopias and utopias in terms of hybrid formations and interdependent categories. In the case of the plays examined in this article one could reverse the argument mentioned by Gordin, Tilley and Prakash that "[e]very utopia always comes with its implied dystopia - whether the dystopia of the status quo, which the utopia is engineered to address, or dystopia found in the way this specific utopia corrupts itself in practice" (2010:2) and argue that dystopias come with their implied utopias - whether the ones from which they have evolved or the ones towards which they struggle, or more accurately both simultaneously.

All three plays present societies divided along gender lines and attempts to change the imbalance of powers and violence associated with it. And although the main thrust of these dystopian/utopian visions is towards questioning the power systems based on gender discrimination, they also include - with varying emphasis - the questions of exclusionary practices concerning other underprivileged groups, thus blurring polarized categories. In The Rising Generation - through substitution - reference is made to discrimination of Jews and other races (the Holocaust and slavery), in More Light questions of absolute power and patriarchal rule are extended to include - beside women - also men excluded from their share in the patriarchal power, in Lysistrata the main focus falls on solidarity — or the lack thereof - with women representing underprivileged social groups and occupations.

Perhaps the most important element that unites the three plays examined in this article is the self-ironic and deconstructive attitude to both dystopia and utopia that they present. 
It is connected with mixing conventions, genres and registers as well as employing experimental theatre forms. In a sense the plays' experimentation further deconstructs the presented visions by questioning the safety of conventional theatre situations, exposing gender clichés and employing distancing techniques. The interactive scenario of The Rising Generation, involving the audience in the utopian escape from the planet, the double cross-dressing in More Light (the original production) and the carnivalesque exaggeration and Brechtian alienation techniques in Lysistrata - foreclose the possibility of a neat ending. All the plays under consideration offer the possibilities ascribed to new critical dystopias - the ones which through "ambiguous open endings [...] maintain the utopian impulse within the work" (Baccolini and Moylan 2003: 7), as they demand more critical and self-reflexive readings.

\section{Bibliography}

Baccolini Raffaella, Moylan Tom (2003), Introduction: Dystopia and Histories [in:] Dark Horizons: Science Fiction and the Dystopian Imagination, eds. Baccolini R., Moylan T., Routledge, New York.

Berger James (1999), After the End: Representations of Post-Apocalypse, University of Minnesota Press, Minneapolis.

Donawerth Jane (2003), Genre Blending and the Critical Dystopia [in:] Dark Horizons: Science Fiction and the Dystopian Imagination, eds. Baccolini R., Moylan T., Routledge, New York.

Durband Alan (1969), Introduction [in:] Playbill Two, ed. Durband A., Hutchinson Educational, London.

Gordin Michael D., Tilley Helen, Prakash Gyan (2010), Utopia and Dystopia beyond Space and Time [in:] Utopia/Dystopia: Conditions of Historical Possibility, eds. Gordin M.D., Tilley H., Prakash G., Princeton UP, Princeton.

Greer Germaine (1986), The Madwoman's Underclothes: Essays and Occasional Writings 19681985, Picador, London.

Greer Germaine, Willmott Phil (2000), Lysistrata - The Sex Strike, Aurora Metro Press, London.

Heffernan Teresa (2008), Post-apocalyptic Culture: Modernism, Postmodernism, and the Twentieth-century Novel, University of Toronto Press, Toronto.

Jellicoe Ann (1969), The Rising Generation [in:] Playbill Two, ed. Durband A., Hutchinson Educational, London.

Keyssar Helene (1993), Feminist Theatre: An Introduction to Plays of Contemporary British and American Women, MacMillan, Basingstoke. 
Lavery Bryony (2005a), Interviewed by Lizbeth Goodman [in:] Feminist Stages: Interviews with Women in Contemporary British Theatre, eds. Goodman L., Gay J. de, Routledge, London. - (2005b), Afterword: 'Guerillas in the Mist': Sightings of, and Observations on, Feminists in British Theatre [in:] Feminist Stages: Interviews with Women in Contemporary British Theatre, eds. Goodman L., Gay J. de, Routledge, London.

- (2007), More Light [in:] Bryony Lavery: Plays One, Faber and Faber, London.

Lorek-Jezińska Edyta (2005), Between the generic he and the generic she: the cultural re-definition of gender polarity in Ann Jellicoe's "The rising generation" [in:] S/he...embracing/wrestling genders: cultural spaces for a re-definition of the political, eds. Pantuchowicz A., Rachwat T., Wydawnictwo ATH, Bielsko-Biała.

- (2009), Burial, Excavation and Cannibalism: The Body's Discursivity in Bryony Lavery's Drama [in:] The Body, eds. Dobosiewicz I., Gutorow J., Opole UP, Opole.

Łanowski Jerzy (1981), Wstęp [in:] Arystofanes. Trzy komedie, trans. J. Ławińska-Tyszkowska, Zakład Narodowy im. Ossolińskich, Wrocław.

Mohr Dunja M. (2005), Worlds Apart? Dualism and Transgression in Contemporary Female Dystopias, McFarland and Company, Jefferson.

Moi Toril (1986), Feminist Literary Criticism [in:] Modern Literary Theory: A Comparative Introduction, eds. Jefferson A., Robey D., Batsford B.T., London.

- (1994), Sexual/Textual Politics: Feminist Literary Theory, Routledge, London.

Willmott Phil (2000), A Guide to Production Performance Style [in:] Lysistrata — The Sex Strike, Aurora Metro Press, London. 